\title{
Key enablers to implement sustainable supply chain management practices: An Indian insight
}

\author{
Kausar $^{\mathrm{a}}$, Dixit Garg ${ }^{\mathrm{b}}$ and Sunil Luthra ${ }^{\mathrm{e}^{*}}$
}

\begin{tabular}{l}
\hline C H R O N I C L E \\
\hline Article history: \\
Received July 2, 2016 \\
Received in revised format \\
September 10, 2016 \\
Accepted October 212016 \\
Available online \\
October 25 2016 \\
\hline Keywords: \\
Sustainable supply chain \\
management (SSCM) \\
Key enablers \\
Interpretive Structural \\
Modeling (ISM) \\
MICMAC analysis
\end{tabular}

${ }^{a}$ Department of Mechanical Engineering, National Institute of Technology, Kurukshetra-136119, Haryana, India

${ }^{b}$ Professor, Department of Mechanical Engineering, National Institute of Technology, Kurukshetra-136119, Haryana, India ${ }^{\circ}$ Lecturer, Department of Mechanical Engineering, Government Polytechnic, Jhajjar-124103, Haryana, India

\section{Introduction}

\begin{abstract}
A B S T R A C T
The role of sustainability in supply chain is becoming critical due to increasing environment related problems and societal issues. Sustainable Supply Chain Management (SSCM) helps in reducing environmental degradation as well as social and economic implications. SSCM practices in Indian industries are in initial stage of implementation and industries find difficult to implement. Therefore, in present research, key enablers to initiate SSCM are recognized and analyzed. This research has recognized twelve enablers with the help of previous researches and expert survey. A Structural framework has been drawn with the use of Interpretive Structural Modeling (ISM) technique, to understand the relationship among the identified enablers and also to find the reliance of one on another. Further, MICMAC analysis has been employed for evaluating these identified enablers in accordance with Driving power and Dependence power. From ISM Methodology "Government policies and supportive systems" is found to be a key bottom enabler, which is important to implement the SSCM in Indian industries. For further future perspective, Decision Making Trial and Evaluation Laboratory (DEMATEL), can also be recommended for evaluation purpose. Present research may be helpful to find the importance of different enablers for successful implementation of SSCM in Indian industries.
\end{abstract}

In recent scenario, operations research has introduced sustainability as a leading topic in supply chains. The need has been raised in organizations to think beyond economic aspect, such as to minimize cost and operational profitability. The analysis of sustainability refers that the businesses should be optimized according to the three parameters, such as social and environmental (Ahi \& Searcy, 2013; Beske, 2012; Beske \& Seuring, 2014; Pagell \& Schevchenko, 2014). Furthermore, in managerial decisions, there is a need to understand these three dimensions, simultaneously (Zhou et al., 2000).

The world economy has much increased, and the population has risen at the fastest rate along with increasing fuel consumption and also industries have grown in many areas. This growing economy has influenced the utilization of natural resources and their consumption in an improper manner (Dehghanian \& Mansour, 2009). The cause of transforming supply chain is considered to be the influence and results of different environmental conditions and requirements to change toward * Corresponding author E-mail address: sunilluthra1977@gmail.com (S. Luthra) 
sustainability, environmental degradation is found to be Supply Chains (SCs), those have become major sources of waste emission, global warming, and acid rain (Muduli \& Barve, 2011). Because of this, the value of human life has affected badly in many ways, like increasing temperature of the surroundings, exhausted ozone layer and reduction of biodiversity. Due to these reasons, sustainability has introduced in industries for complete balancing of all branches together, such as social, environmental and economic, that are proven to be more beneficial for organizations, global population and future generation (Brito and Laan, 2010; Chkanikova, 2012).

Many reputed companies have integrated sustainability into their supply chains because of such environmental problems, e.g. IBM, Hewlett-Packard, McDonald's, Wal-Mart, Patagonia and Xerox (Maignan et al., 2002; Markley \& Davis, 2007). Business sustainability allows corporations and their supply chain partners to have new ideas for social welfare, lowering wastage of energy and natural habitat, cutting extra materials and regulatory ongoing expenses, and generating an improved amount of total money transfer, all of which are even more important than in the slowdown of the economy and less financial growths (Berns et al., 2009; Beske \& Seuring, 2014). Jayaratne et al. (2011) found that sustainability is considered to be an innovative approach, including changes in previous existing processes, new technology, improved methods of management, new production systems, which may bring changes in Supply Chain Management (SCM): including old policies of supply chains, production activities, inventory of goods and product management, and dispatching. Consequently, sustainability is found to be a major aspect of continuous improvement for any enterprises and it is of great importance to find the success variable which may help in executing sustainable initiatives.

The aim of this study is described in three manifolds are as follows.

1. Identification of key enablers to Sustainable Supply Chain Management (SSCM) by considering an outlook of Indian industries,

2. Accomplish a relationship among the several key enablers, using ISM methodology and develop a structural framework showing the reliance of one on another,

3. Analyzing the variable using MICMAC theory and considering the managerial implications of this study to find an avenue for research in the future.

ISM methodology (Jayant \& Azhar, 2014; Dubey et al., 2015; Prasad \& Chalapathi, 2015) is used to find contextual relationships among these identified enablers. It is used to identify, summarize the relationships of variables, which is used to define the problem in graphical form. It is used in complex situations to find the order of variable in which they can arrange and find the best solution. MICMAC theory is used to classify the enablers on the basis of driving and dependence power. The results obtained by these methods may prove to be useful for an Indian organization to execute the sustainable practices in their supply chains.

\subsection{Composition of the Paper}

Literature review concerning Sustainable Supply Chain Management (SSCM) and key enablers to execute the sustainable practices in Indian organizations are covered in Section 2. Section 3 consists the explanation of the methedology used. In Section 4, data is analyzed and results are discussed. Manergial impliction of study, discussion have been covered in the Section 5. Conclusion and future scope have been covered in Section 6.

\section{Literature review}

This section reviews the liteature on SSCM and identifies key enablers to execute the sustainable practices in Indian organizations. 


\subsection{Sustainable Supply Chain Management (SSCM)}

Sustainable supply chain (SSC) can be defined as "management of raw materials and services from suppliers to manufacturing/service producer to customer and back with improvement of the social and environmental impacts explicitly considered". As for SSC Management (SSCM), it is "the management of material, information and capital flows as well as cooperation among companies along the supply chain while taking goals from all three dimensions of sustainable development, i.e., economic, environmental and social, into account which are derived from customer and stakeholder requirements" (Seuring \& Müller, 2008). Table 1 shows the literature review dealing with supply chain sustainability.

\section{Table 1}

Literature review dealing with supply chain sustainability

\begin{tabular}{|c|c|}
\hline Researchers & Description of the study \\
\hline $\begin{array}{l}\text { Nielsen and } \\
\text { Jørgensen (2015) }\end{array}$ & $\begin{array}{l}\text { They claimed the need to increase sustainability in regards of society, the require method should be developed to } \\
\text { govern analysis of sustainability, which would help in the transition from old supply chain objectives to } \\
\text { sustainable supply chain objectives. }\end{array}$ \\
\hline $\begin{array}{l}\text { Subramaniam et } \\
\text { al. }(2014)\end{array}$ & $\begin{array}{l}\text { They have addressed the perceptions of managing risks and opportunities associated with carbon pricing and } \\
\text { emissions management. The factors that affected the extent to which carbon-related risks and opportunities were } \\
\text { integrated into the organization's formal enterprise risk management system were examined. Their results showed } \\
\text { that carbon risk integration is positively connected with the existence of an official carbon strategy, senior } \\
\text { management involvement, internal audit oversight, personnel and funds availability and energy sector }\end{array}$ \\
\hline
\end{tabular}
membership.

Luthra and They found ten hurdles in implementing sustainable supply chain management. They tried to establish the Haleem (2015) linkage between hurdles to introduce SSCM in Indian automobile sector using ISM methodology.

Amindoust et al. They introduced a model based on fuzzy ranking for supplier selection for sustainable supply chain management (2012) with the consideration of case study. They described the standards and sub-standards for no of suppliers for evaluation and ranking of suppliers. In the evaluation process, decision makers' opinions have been used.

Büyüközkan and They proposed a model considering Multi Criteria Decision Making (MCDM) based on fuzzy theory for Çifçi (2011) an effective, sustainable supplier evaluation based upon five criteria, namely firm, financial accomplishment, excellence in services, technology and social authority and environment appropriateness. Supplier's environmental performance and image were identified as the responsible factor of environmental performance of different organizations. A case study had been used for supplier's evaluation.

Pagell and $\mathrm{Wu}$ They proposed a model which considered the new values and capabilities, as well as the development of new (2009) behaviors along the supply chain. The new ideas towards sustainability orientation motivates organizational capacity to reflect new values internally and capability to be linked to SCM. Having such considerations, firms are considered to be proactive and committed if their business model is aligned with natural habitat and civilization elements of sustainability.

Seuring and They recognized that government and customer stakeholders create pressure on companies to develop strategies Müller (2008) based on two decisions, which are: "risk management of suppliers" and "sustainable product management". These strategies are developed by assuming risks of economic viability, smaller range of suppliers and prolonged relationships, along with inclusion of TBL into supply chains.

Carter and They recognized the three most important parameters of Sustainable supply chain management (SSCM) which Rogers (2008) are, ecological, financial and societal aspects and these are essential for long term development of companies and their survival.

Porter and They identified two reasons which were responsible for organization's failure of not considering public affairs Kramer (2006) like, the result of a scandal from business ethics into Enron's breakdown and elimination of customers from the Nike company because of bad ethical behavior of labors.

Guide and van They found "Closed loop supply chain management" (CLSC) which is defined as the process to increase the Wassenhove value creation by designing, controlling and operating a system.

(2006)

Kleindorfer et al. They reviewed previous 50 issues which were covered in the publication of Production and Operations (2005) Management with the considerations of various sustainability themes.

Gungor and They discussed a new approach in manufacturing: 'environmentally responsive production and recycling of Gupta (1999) product', including an integrated approach in design, selection of material, manufacturing operations, dispatching of the product to the consumers, and product's management after end-of-life. Many reviews were done on product life-cycle analysis: design of product, manufacturing, use, and recycling/recovery. The 'environmentally responsive manufacturing' considers two issues, such as better knowledge of product's life cycle and influence on the environment at each of its life stages, and improved decision making towards the design, development and production of the product in such a way to maintain it at required stage.

Carter and Ellram They continued the research on reverse logistics with a step forward towards lowering the material wastage in (1998) forward flow, further use of material, and recycling is being facilitated. From this view, factors that impact the reverse logistics were found, such as internal, external and environmental.

Fleischmann et al. They reviewed the quantitative models regarding backward logistics, they classified this as a planning of (1997) dispatching, inventory control, and planning of production. Based on these classifications, the effort is made to reuse the products and find mathematical models for more efficient logistics. 


\subsection{Identification of Key Enablers to Implement Sustainable Supply Chain Management}

Organizations in India have made a larger market in the world and growth rate is very fast. The Indian automobile sector has secured 10th position in the world and has second rank in two wheeler and four in commercial vehicles. In most of Indian industries, sustainability has grown into supply chain management with clear explanation because of less available resource, greenhouse gas emissions, degradation of natural resources and consumers' awareness about labor issues.

Based on the concept of the Triple Bottom Line (TBL), Sustainable Supply Chain Management (SSCM) is applied in industries (Gold, 2010; Linton et al., 2007; Seuring \& Müller, 2008; Beske \& Seuring, 2014; Seuring, 2011).

Triple Bottom Line (TBL) is comprised of three branches, i.e. Environment, Social and Economic. These three branches are described as follows: Framework of Sustainable Supply Chain Management. Environment: It addresses the surroundings problems such as, devastation of natural capitals, depletion of ozone layer, consent of meeting standards etc.

Society: It refers to the diversification of jobs (child labor, forced labor, etc.), equality in opportunities, human rights etc.

Economics: It covers the consistency, monetary progress, managing risks, return on investment (ROI) etc.

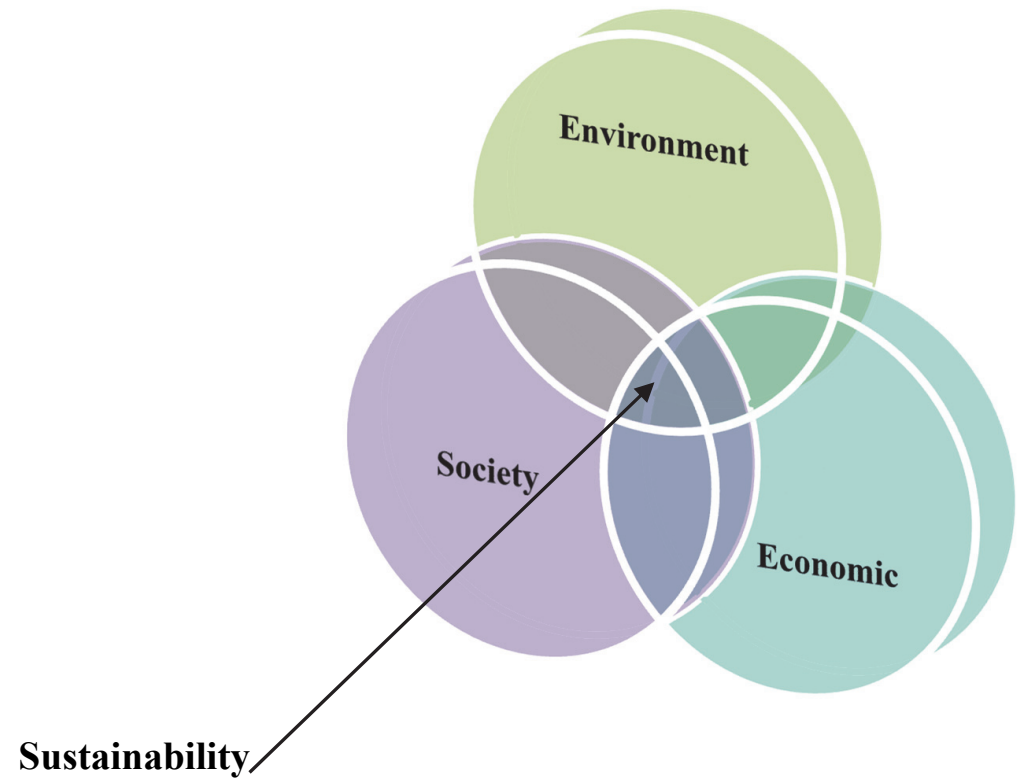

Fig. 1. Sustainability concept-Triple bottom line

Seuring and Müller's (2008), addressed Triple Bottom Line (TBL) (Shown in Fig. 1) must be collaborated into business because sustainable supply chain management can be conceptualized using it. An extensive literature review approach has followed to find out the drivers which may prove to be helpful in implementing SSCM (Easterby-Smith et al., 2002). Expert opinions have also suggested some helpful enabler to Sustainable Supply Chain Management (SSCM). In current study, the collective approach has identified twelve enabler to SSCM, which have been explained above.

\subsubsection{Decision making Strategies}

The most developed and supportive strategic planning is the most important issue to implement SSCM because of the changing technology trend, customer's never ending desire, supplier relationships, stakeholder's pressure, competitive market conditions etc. (Sarkis, 1998). Most of Indian organization is emphasizing on how to plan the strategies so as to evaluate the social viability and environmental 
conditions to have an improved competitive benefits of creating more opportunities in businesses (Barari et al., 2012; Chan et al., 2012; Muduli et al., 2013).

\subsubsection{Adequate top management support}

In every firm, upper management engages in a key role for the successful implementation of SSCM because of its powers and responsibilities (Zhu et al., 2007a, 2007b; Zhu et al., 2008a, 2008b). Uppermost management decides and plans each and every activity which are to be performed in all departments (Min \& Galle, 2001). It may or may not approve the ideas to adopt new market policies, practices and sustainable activities. The commitment of top management is essential for the continuous progress of all firms (Hamel \& Prahalad, 1989; Yu \& Hui, 2008). Manufacturing strategies and business strategies are the main areas of progress in which top management motivates the employees to change towards environmental and social responsibilities (Digalwar \& Metri, 2004; Yu \& Hui, 2008). Uppermost management has remarkable capacity to encourage workers to implement SSCM by providing them wages/incentives and special rewards. Pressures from stakeholder and the demands of customer push top management to commit towards Sustainable Supply Chain Management (SSCM) (Walker \& Jones, 2012; Luthra et al., 2014a, 2014b). Committed management is of prime importance for successful implementation of SSCM.

\subsubsection{Government policies and supportive systems}

Government support is a major reason for any organization to get into new processes and changing policy for the environment and society. In all firms positive motivation is brought up by a country's government so that they would be able to think beyond economic parameter and serve development in the environment and society. The provision of new policies for pollution control and preventing production of destructive materials those affect the environment very badly can be helped by the Government regulatory bodies (Scupola, 2003). The support of government plays a key role in providing subsidies for process and encouraging employees to implement SSCM in their organizations because it sets the regulatory laws every Indian organization (Mudgal et al., 2009; Mudgal et al., 2010). The legislative authority gives support in fulfilling monitory requirement so as to provide education and training to manpower about sustainable development. People are gaining more interest in environmental issues because of government support (Balasubramanian, 2012).

\subsubsection{Provision of Information technology}

In any organization Information technology (IT) plays a crucial role to support the operations involved in supply chain process and upgrade its performances. It provides a support system for various activities of SSCM such as product design and development for the surrounding, retrieval and recycling process (Ravi \& Shankar, 2005). Resource's optimization can be done by using IT application which may help in planning, execution and collaboration and hence, decreases the need of resources (Cognizant, 2008). Gathering and delivery of information for products, material and different resource require IT for their processing (Sarkis et al., 2007). IT enables electronic transfer of information due to which wastage and proper utilization is reduced. Soft wares are designed for better understanding of tool's life and for evaluating the cleanliness of different designs (Sarkis and Zhu, 2008).

\subsubsection{Standards in human resources}

Human resources are considered as an important asset in every reputed organization. Highly qualified and trained personnel help in guiding and supporting new technologies (Lee et al., 2008; Sarkis et al., 2010). Hiring of quality workers who have knowledge of every field is assumed as an important aspect of a successful implementation of SSCM (Luthra et al., 2011) 


\subsubsection{Employees commitment towards SSCM}

The interaction and communication among employees to gather information about sustainable activities takes a vital position in the successful implementation of Sustainable Supply Chain Management. Intra organizational cross functional communication helps to understand the strategic directions and goals. Qualified and skilled worker accept challenge easily and commit to innovative practices, although the charges incurred to employ the personnel may increase (Tornatzky \& Fleischer, 1990).

\subsubsection{Management within the organization}

Protective and working environment is a major requirement for any employee to ensure the safety from injuries and health protection (Trowbridge, 2001). Proper workplace management and housekeeping practices are extremely vital for implementing and adopting SSCM practices (Toke et al., 2012). Safety in the workplace is an important issue for unions of employees as they always push the top managers to fulfill their demands for safety. Although proper workplace management costs very little but help in achieving good housekeeping practices, workplace safety and enhancing morale of employees, which is going to help organizations to achieve their sustainable progress (Muduli \& Barve, 2013).

\subsubsection{Motivation to suppliers \& vendors towards sustainable practices}

The relationship between manufacturers and suppliers should be good enough to maintain a close network of information sharing about sustainable practices and social awareness. Suppliers of minor and major scaled enterprises should be aware of surrounding, legislative and eco-design issues (Winkler, 2010). Rewards and special incentives are also provided to suppliers for their contribution in improving environmental conditions promoting cleaner production (Muduli et al., 2013b).

\subsubsection{Adoption of new technologies}

Many companies face problems in finding solutions for environmental issues because of obsolescent techniques and methods. Adoption of new technologies is essential to innovate business culture, develop new ideas for product development and also to enhance the world economy (Digalwar \& Metri, 2004; Mudgal et al., 2009; Kaushik et al., 2014). Betterment in technology is desirable for savingenergy and having a more favorable impact on the environment, making changes in manufacturing technology ( Muduliand Brave, 2011).

\subsubsection{Consciousness of customers toward sustainable movements}

The characteristics of products and services must be set in such a way that they are capable of fulfilling customer needs for sustainable resolution (Zhu et al., 2008a, 2008b). From a survey it has been recognized that about $75 \%$ customer attracted to a product by company's reputation and $80 \%$ goes to the environment favorable products (Lamming \& Hamapson, 1996; Chien \& Shih, 2007a, 2007b; Kumar et al., 2014). Customer's expectation level varies from firm to firm based upon their size and market reputation. Highly reputed organizations are more conscious than less reputed due to high expectations of customer. The bottom line is directly affected by Customer's expectations (Walker et al., 2008). Indian organizations invest in advertisement for environment friendly products for making aware, customers towards sustainable development. Awareness of customer is important to enhance company's reputation and volume of sales. Companies are highly influenced by customers demand so the awareness of customer is a very important driver (Mudgal et al., 2009, 2010).

\subsubsection{Economic advantages}

The knowledge of economics, environment and social issues helpmanagers and researchers to connect sustainability with the supply chain. There is a great demand of incorporating three sustainability issues, 
i.e. surrounding, public civilization and financial difficulties in the supply chain. Environmental pitfall must be understood by practitioners and managers so that they can have the opportunitiescreating by them (Ageron et al., 2012). The reputation of customers, vendors and shareholders increases by combining triple bottom line and also rises economic benefits.(Gopalakrishnan et al., 2012).

\subsubsection{Competitiveness of companies toward SSCM}

Motivating employees toward SSCM is beneficial in the improvementof firm's competitiveness, market image and new market development (Chen et al., 2006). It can make a huge difference between the competitors and also influenced the plan, success (Nimawat \& Namdev, 2012). The adoption of sustainable SSCM activities is favorable for competitive growth and more voluntary actions (Wang \& Sarkis, 2013; Luthra et al., 2015).

\section{Methodology}

Interpretive Structural Modeling (ISM): It was adopted in 1973 by Warfield to evaluate the enabler to SSCM. The relationship between the identified enabler is represented by hierarchal model i.e. ISM model. This method is employed by several enterprises to find out solutions in complex situations. The judgment and analysis are performed to find out how these enablers are dependent on each other (Singh et al., 2003; Luthra et al., 2012; Ansari et al., 2013; Kumar et al., 2013). This technique undergoes eight basic steps, which are discussed above:

Step 1: In this step, with the help of an extensive literature reviewand expert survey key enablers to Sustainable Supply Chain Management (SSCM) implementation are identified.

Step 2: This step includes the development of a contextual relationship between the enablers recognized in the above step.

Step 3: The formation of Structural Self-Interaction Matrix (SSIM) is involved in this step, and this state the relationship between the enablers, which are denoted by 4 symbols i.e. V, A, X and O.

Step 4: A reachability matrix is formed with the help of SSIM. In this step, transitivity rule is applied. Step 5: This step involves partitioning of distinct levels.

Step 6: Based on the relations in Reachability matrix, A digraph is created by removing transitive links. Step 7: The digraph developed in the previous step is changed an ISM model by the conversion of variable nodes into statements.

Step 8: This step involves a complete review to find out the conceptual inconsistencies, and necessary modifications are done.

Moreover, MICMAC analyzes the results obtained through ISM model, and also identifies the driver and dependence power of the key enablers. A hierarchal representation of the key enablers is shown by ISM Model.

\section{Data analysis and results}

\subsection{Development of Structural Self-Interaction Matrix (SSIM)}

It shows a pairwise relationship between different enablers, which has a critical place in executing Sustainable Supply Chain Management (SSCM) practices. Four different symbols are used to show the relationship between these enablers. Let, $\mathrm{i}$ and $\mathrm{j}$ are notation for variable, then four symbols are given as:

' $V$ ' refers that $i$ enabler will support to achieve to $j$ enabler;

' $A$ ' refers that $j$ enabler will support to achieve to $i$ enabler;

' $X$ ' refers that both $i$ and $j$ support each other;

' $\mathrm{O}$ ' refers that both $\mathrm{i}$ and $\mathrm{j}$ are not connected to each other. 
Based on above symbols, Structural Self-Interaction Matrix (SSIM) is formed as shown in (Table 2).

Table 2

Structural Self-Interaction Matrix

\begin{tabular}{|c|c|c|c|c|c|c|c|c|c|c|c|c|c|}
\hline $\begin{array}{l}\text { S. } \\
\text { No. }\end{array}$ & Key Enablers to SSCM & 12 & 11 & 10 & 9 & 8 & 7 & 6 & 5 & 4 & 3 & 2 & 1 \\
\hline 1. & Decision making Strategies & $\mathrm{V}$ & V & $\mathrm{V}$ & V & V & V & V & V & $\mathrm{V}$ & A & A & $\mathrm{X}$ \\
\hline 2. & Adequate top management support & V & V & V & V & V & V & V & V & V & A & $\mathrm{X}$ & \\
\hline 3. & Government policies and supportive systems & V & V & V & V & V & V & V & V & V & $\mathrm{X}$ & & \\
\hline 4. & Provision of Information technology & V & V & $\mathrm{X}$ & $\mathrm{X}$ & V & $\mathrm{X}$ & $\mathrm{X}$ & $\mathrm{X}$ & $\mathrm{X}$ & & & \\
\hline 5. & Standards in human resources & V & V & V & $\mathrm{X}$ & V & $\mathrm{X}$ & V & $\mathrm{X}$ & & & & \\
\hline 6. & Employees commitment towards SSCM & V & V & V & $X$ & V & $\mathrm{X}$ & $\mathrm{X}$ & & & & & \\
\hline 7. & Management within the organization & V & V & V & $X$ & $\mathrm{O}$ & $\mathrm{X}$ & & & & & & \\
\hline 8. & $\begin{array}{l}\text { Motivation of suppliers \& vendors towards } \\
\text { green practices }\end{array}$ & V & V & $\mathrm{X}$ & A & $\mathrm{X}$ & & & & & & & \\
\hline 9. & Adoption of new technologies & V & V & V & $\mathrm{X}$ & & & & & & & & \\
\hline 10. & $\begin{array}{l}\text { Consciousness of customers toward sustainable } \\
\text { movements }\end{array}$ & V & V & $\mathrm{X}$ & & & & & & & & & \\
\hline 11. & Economic advantages & $\mathrm{X}$ & $\mathrm{X}$ & & & & & & & & & & \\
\hline 12. & Competitiveness of companies toward SSCM & - & & & & & & & & & & & \\
\hline
\end{tabular}

\subsection{Reachability Matrix}

Structural self-interaction matrix (SSIM) is transformed into Initial reachability Matrix in which the symbols formed in previous step is changed into binary digits. This binary matrix contains 0 and 1 and follows the rules:

- If the value $(i, j)$ occurred in SSIM is $V$, then reachability matrix will obtain 1 for $(i, j)$ and 0 for $(j$, i).

- If the value $(i, j)$ occurred in SSIM is $A$, then reachability matrix will obtain 0 for $(i, j)$ and 1 for $(j$, i).

- If the value $(i, j)$ occurred in SSIM is $X$, then reachability matrix will obtain 1 for $(i, j)$ and 1 for $(j$, i).

- If the value $(i, j)$ occurred in SSIM is $\mathrm{O}$, then reachability matrix will obtain 0 for $(i, j)$ and 0 for $(j$, i).

Using above rule this, initial reachability matrix (shown in Table 3 ) is obtained.

Table 3

Initial Reachability Matrix

\begin{tabular}{|c|c|c|c|c|c|c|c|c|c|c|c|c|c|}
\hline S. No. & Key Enablers to SSCM & 1 & 2 & 3 & 4 & 5 & 6 & 7 & 8 & 9 & 10 & 11 & 12 \\
\hline 1. & Decision making Strategies & 1 & 0 & 0 & 1 & 1 & 1 & 1 & 1 & 1 & 1 & 1 & 1 \\
\hline 2. & Adequate top management support & 1 & 1 & 0 & 1 & 1 & 1 & 1 & 1 & 1 & 1 & 1 & 1 \\
\hline 3. & Government policies and supportive systems & 1 & 1 & 1 & 1 & 1 & 1 & 1 & 1 & 1 & 1 & 1 & 1 \\
\hline 4. & Provision of Information technology & 0 & 0 & 0 & 1 & 1 & 1 & 1 & 1 & 1 & 1 & 1 & 1 \\
\hline 5. & Standards in human resources & 0 & 0 & 0 & 1 & 1 & 1 & 1 & 1 & 1 & 1 & 1 & 1 \\
\hline 6. & Employees commitment towards SSCM & 0 & 0 & 0 & 1 & 0 & 1 & 1 & 1 & 1 & 1 & 1 & 1 \\
\hline 7. & Management within the organization & 0 & 0 & 0 & 1 & 1 & 1 & 1 & 0 & 1 & 1 & 1 & 1 \\
\hline 8. & Motivation of suppliers \& vendors towards green practices & 0 & 0 & 0 & 0 & 0 & 0 & 0 & 1 & 0 & 1 & 1 & 1 \\
\hline 9. & Adoption of new technologies & 0 & 0 & 0 & 1 & 1 & 1 & 1 & 1 & 1 & 1 & 1 & 1 \\
\hline 10. & $\begin{array}{l}\text { Consciousness of customers toward sustainable } \\
\text { movements }\end{array}$ & 0 & 0 & 0 & 1 & 0 & 0 & 0 & 1 & 0 & 1 & 1 & 1 \\
\hline 11. & Economic advantages & 0 & 0 & 0 & 0 & 0 & 0 & 0 & 0 & 0 & 0 & 1 & 1 \\
\hline 12. & Competitiveness of companies toward SSCM & 0 & 0 & 0 & 0 & 0 & 0 & 0 & 0 & 0 & 0 & 1 & 1 \\
\hline
\end{tabular}

In next step, initial reachability matrix is converted into final reachability matrix. The final reachability matrix is constructed by considering the rule of transitivity, which refers that if a variable ' 1 ' belongs to ' 2 ' and ' 2 ' belongs to ' 3 ', then ' 1 ' is importantly belongs to ' 3 '. This matrix is shown in (Table 4). 
Table 4

Final Reachability Matrix

\begin{tabular}{|c|c|c|c|c|c|c|c|c|c|c|c|c|c|c|}
\hline $\begin{array}{l}\text { S. } \\
\text { No. }\end{array}$ & Key Enablers to SSCM & 1 & 2 & 3 & 4 & 5 & 6 & 7 & 8 & 9 & 10 & 11 & 12 & $\begin{array}{l}\text { Driving } \\
\text { Power }\end{array}$ \\
\hline 1. & Decision making strategies & 1 & 0 & 0 & 1 & 1 & 1 & 1 & 1 & 1 & 1 & 1 & 1 & 10 \\
\hline 2. & Adequate top management support & 1 & 1 & 0 & 1 & 1 & 1 & 1 & 1 & 1 & 1 & 1 & 1 & 11 \\
\hline 3. & $\begin{array}{l}\text { Government policies and } \\
\text { supportive systems }\end{array}$ & 1 & 1 & 1 & 1 & 1 & 1 & 1 & 1 & 1 & 1 & 1 & 1 & 12 \\
\hline 4. & $\begin{array}{l}\text { Provision of Information } \\
\text { technology }\end{array}$ & 0 & 0 & 0 & 1 & 1 & 1 & 1 & 1 & 1 & 1 & 1 & 1 & 9 \\
\hline 5. & Standards in human resources & 0 & 0 & 0 & 1 & 1 & 1 & 1 & 1 & 1 & 1 & 1 & 1 & 9 \\
\hline 6. & $\begin{array}{l}\text { Employees commitment towards } \\
\text { SSCM }\end{array}$ & 0 & 0 & 0 & 1 & $1 *$ & 1 & 1 & 1 & 1 & 1 & 1 & 1 & 9 \\
\hline 7. & $\begin{array}{l}\text { Management within the } \\
\text { organization }\end{array}$ & 0 & 0 & 0 & 1 & 1 & 1 & 1 & $1 *$ & 1 & 1 & 1 & 1 & 9 \\
\hline 8. & $\begin{array}{l}\text { Motivation of suppliers \& vendors } \\
\text { towards sustainable practices }\end{array}$ & 0 & 0 & 0 & $1 *$ & 0 & 0 & 0 & 1 & 0 & 1 & 1 & 1 & 5 \\
\hline 9. & Adoption of new technologies & 0 & 0 & 0 & 1 & 1 & 1 & 1 & 1 & 1 & 1 & 1 & 1 & 9 \\
\hline 10. & $\begin{array}{l}\text { Consciousness of customers } \\
\text { toward sustainable movements }\end{array}$ & 0 & 0 & 0 & 1 & $1 *$ & $1 *$ & $1 *$ & 1 & 1 & 1 & 1 & 1 & 9 \\
\hline 11. & Economic advantages & 0 & 0 & 0 & 0 & 0 & 0 & 0 & 0 & 0 & 0 & 1 & 1 & 2 \\
\hline 12. & $\begin{array}{l}\text { Competitiveness of companies } \\
\text { toward SSCM }\end{array}$ & 0 & 0 & 0 & 0 & 0 & 0 & 0 & 0 & 0 & 0 & 1 & 1 & 2 \\
\hline & Dependence power & 3 & 2 & 1 & 10 & 9 & 9 & 9 & 10 & 9 & 10 & 12 & 12 & $96 / 96$ \\
\hline
\end{tabular}

\subsection{Partitioning of Levels}

The final reachability matrix formed in (Table 4) is transformed into distinct levels. The reachability and antecedent set are constructed for all key enablers to SSCM. The enabler containing same values of the reachability set and antecedent set is given level $1^{\text {st }}$ and occurred at topmost position in ISM hierarchal model of enablers in implementing SSCM.

After the $1^{\text {st }}$ iteration, the enabler containing $1^{\text {st }}$ level is removed and the procedure is continued with the remaining enablers, until we get levels for each enabler. 8 iterations are performed to obtain all levels. In final iteration, we get distinct levels of every enabler as shown in (Table 5).

Table 5

Partitioning of Levels

\begin{tabular}{|c|c|c|c|c|c|}
\hline $\begin{array}{l}\text { S. } \\
\text { No. }\end{array}$ & Key Enablers to SSCM & Reachability Set & Antecedent Set & Interaction Set & Level \\
\hline 1. & Decision making Strategies & $1,4,5,6,7,8,9,10,11,12$ & $1,2,3$ & 1 & IV \\
\hline 2. & Adequate top management support & $\begin{array}{l}1,2,4,5,6,7,8,9 \\
10,11,12\end{array}$ & 2,3 & 2 & V \\
\hline 3. & Government policies and supportive systems & $1,2,3,4,5,6,7,8 ., 9,10,11,12$ & 3 & 3 & VI \\
\hline 4. & Provision of Information technology & $4,5,6,7,8,9,10,11,12$ & $1,2,3,4,5,6,7,8,9,10$ & $\begin{array}{l}4,5,6,7,8,9 \\
10\end{array}$ & III \\
\hline 5. & Standards in human resources & $4,5,6,7,8,9,10,11,12$ & $1,2,3,4,5,6,7,9,10$ & $4,5,6,7,9,10$ & III \\
\hline 6. & Employees commitment towards SSCM & $4,5,6,7,8,9,10,11,12$ & $1,2,3,4,5,6,7,9,10$ & $4,5,6,7,9,10$ & III \\
\hline 7. & Management within the organization & $4,5,6,7,8,9,10,11,12$ & $\begin{array}{l}1,2,3,4,5,6,7,9 \\
10\end{array}$ & $4,5,6,7,9,10$ & III \\
\hline 8. & $\begin{array}{l}\text { Motivation of suppliers \& vendors towards } \\
\text { sustainable practices }\end{array}$ & $4,8,10,11,12$ & $1,2,3,4,5,6,7,8,9,10$ & $4,8,10$ & II \\
\hline 9. & Adoption of new technologies & $4,5,6,7,8,9,10,11,12$ & $\begin{array}{l}1,2,3,4,5,6,7,9 \\
10\end{array}$ & $4,5,6,7,9,10$ & III \\
\hline 10. & $\begin{array}{l}\text { Consciousness of customers toward sustainable } \\
\text { movements }\end{array}$ & $4,5,6,7,8,9,10,11,12$ & $\begin{array}{l}1,2,3,4,5,6,7,8,9 \\
10\end{array}$ & $\begin{array}{l}4,5,6,7,8,9 \\
10\end{array}$ & III \\
\hline 11. & Economic advantages & 11,12 & $\begin{array}{l}1,2,3,4,5,6,7,8,9,10,11 \\
12\end{array}$ & 11,12 & I \\
\hline 12 & Competitiveness of companies toward SSCM & 11,12 & $\begin{array}{l}1,2,3,4,5,6,7,8,9,10,11, \\
12\end{array}$ & 11,12 & I \\
\hline
\end{tabular}




\subsection{Development of Interpretive Structural Modeling (ISM) model}

Based on level partitioning obtained from shown in (Table 5), a hierarchal model of distinct enabler in implementing SSCM is formed and shown in Fig. 2.

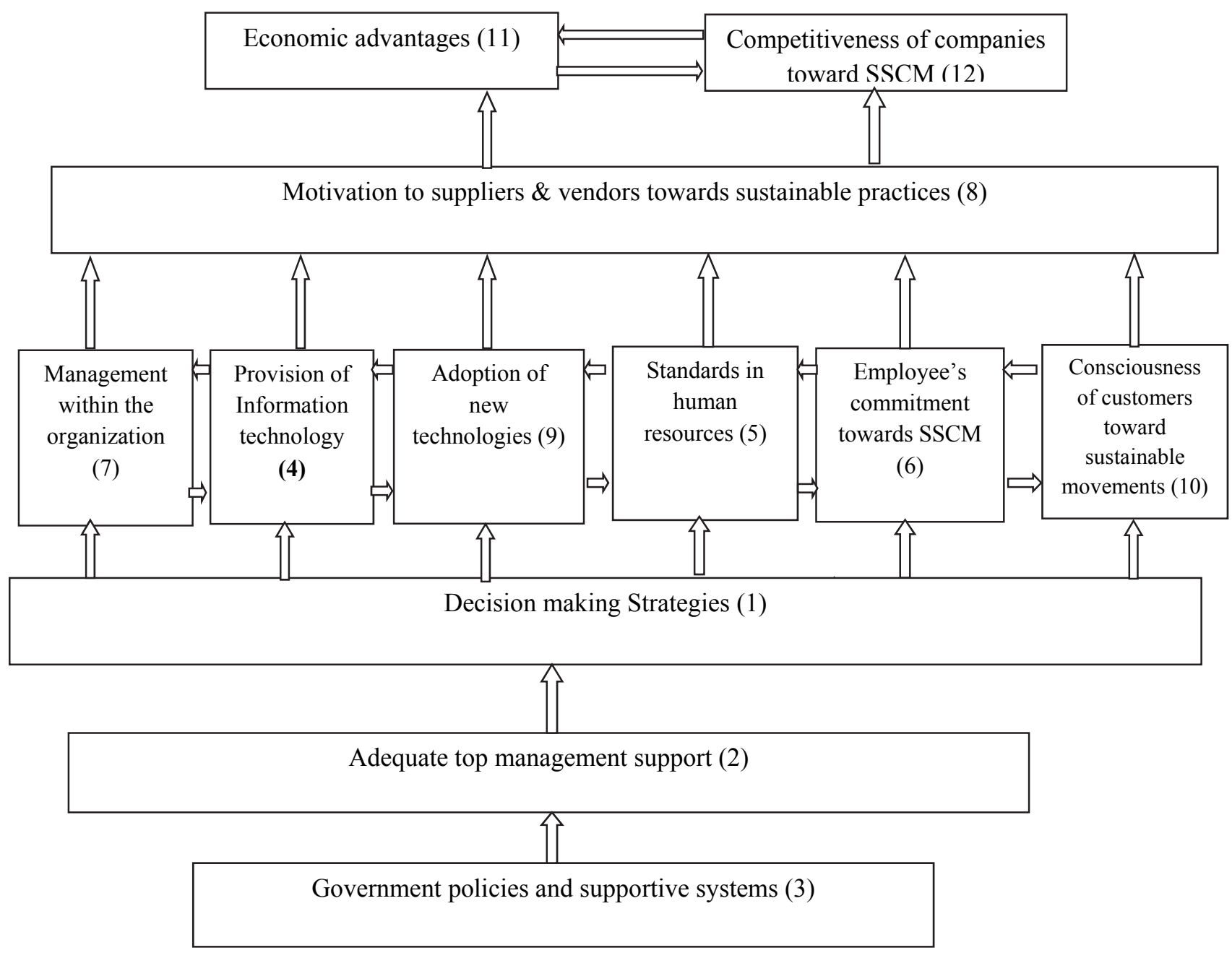

Fig. 2. Interpretive structural model of enablers to implement SSCM

\subsection{MICMAC Analysis and Decision Making}

In the MICMAC analysis, decision making is done for analyzing the driving and dependence power of the enabler 2. It has been recognized that MICMAC analysis works on multiplication properties of matrices (Ravi \& Shankar, 2005; Kannan et al., 2009; Diabat \& Govindan, 2011; Dewangan et al., 2015). The graphical representation between driving power and dependence power is shown in Fig. 3. The enablers are distributed into 4 zones - autonomous, dependent, linkage and independent components. Dependence power and driving power of each enabler is obtained from the final reachability matrix, shown in Table 3 . The enabler having low driving power and low dependence will place in zone I and named as autonomous components. Enablers having low driving power, but high dependence power will place in zone II and are named as dependent components. Enablers having high driving power and dependence power will place in zone III and are named as linkage components. Enablers having high driving power but low dependence power will place in zone IV and are named as driver/independent components. 


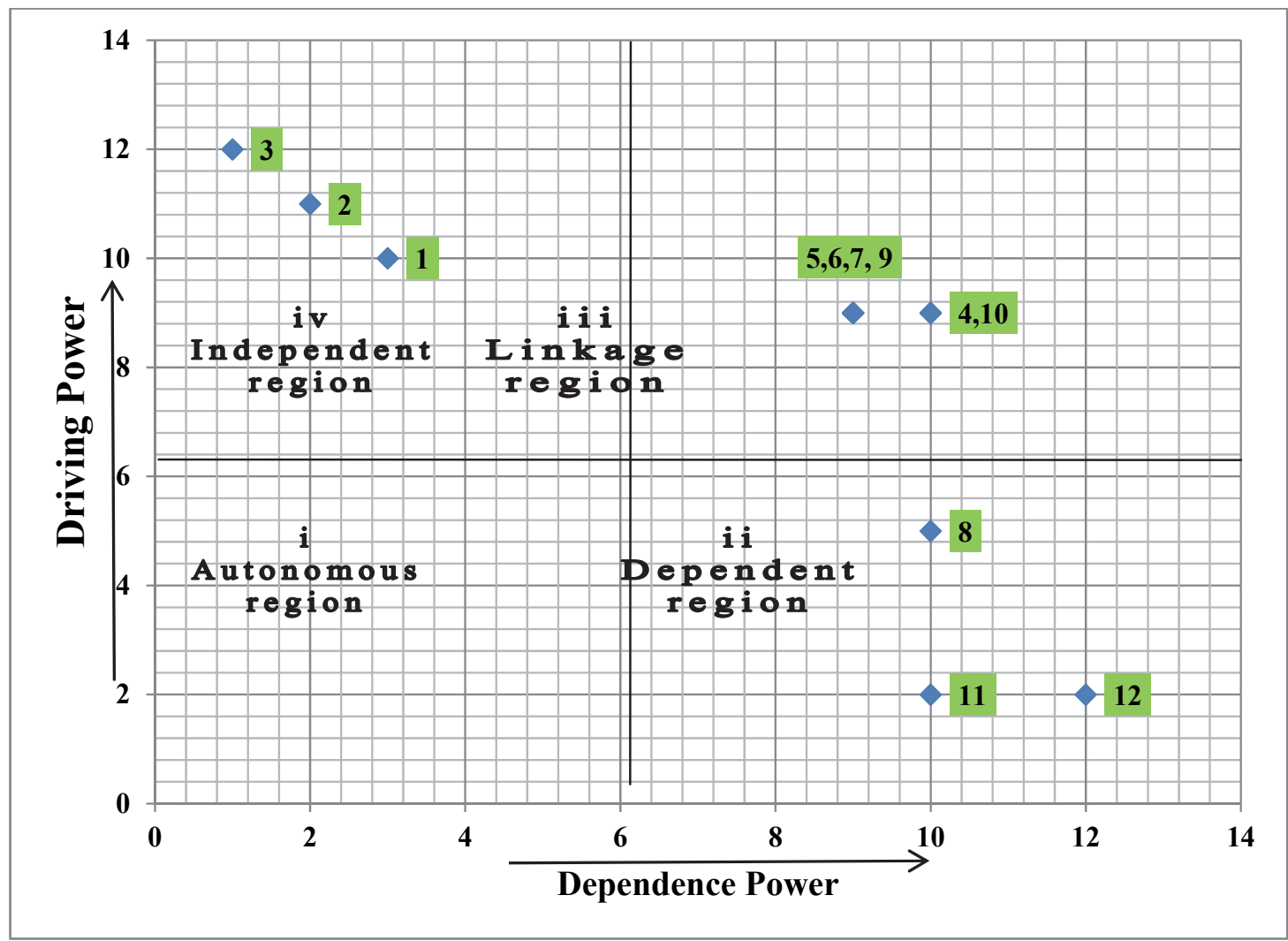

Fig. 3. MICMAC analysis of enablers to implement SSCM

\section{Discussions}

This section involves the discussion based on obtained results and gives a managerial implication of the research.

\subsection{Exploration of Findings}

From ISM model (Shown in figure 2), it is found that "Government policies and supportive systems" is significant enabler to achieve "Adequate top management support" to drive environmental sustainability, which further critical to achieving "Decision making Strategies" which in turn, effect "Management within the organization", "Provision of Information Technology", "Adoption of new technologies", "Improved Standards in human resources", "Employee's commitment towards SSCM", and "Consciousness of customers toward sustainable movements". All of these enablers effect "Motivation to suppliers \& vendors towards sustainable practices" and this enabler will further affect "Economic advantages" and "Competitiveness of companies toward SSCM".

In Fig. 3, it observed that autonomous zone does not contain any enabler. The second zone named as dependent zone. Provision of Information technology (4); Motivation of suppliers \& vendors towards sustainable practices (8); Consciousness of customers toward sustainable movements (10); Economic advantages (11) and Competitiveness of companies toward SSCM (12) have been identified as dependent enablers in SSCM implementation. The next zone named as linkage enabler. In this work, Standards in human resources (5); Employees' commitment towards SSCM (6); Management within the organization (7); and Adoption of new technologies (9) have been identified as a linkage zone enabler; and occurred at the middle level in ISM hierarchy. The Last zone named independent or driver zone. In this work, Decision making Strategies (1); Adequate top management support (2); and Government policies and supportive systems (3) have been found as independent or driver zone barriers and lies on the bottom of ISM hierarchy. 


\subsection{Manergial Implications of the Study}

In the present study, we try to establish a relationship among the key enabler to Sustainable Supply Chain Management (SSCM). Using such consideration, we strive to find the behavior of every enabler which may affect each other and find the importance of each one. It is essential for uppermost authority and policy changers to understand the importance of the elements in every aspect because their influence can affect the execution of Sustainable Supply Chain Management.

The priority of the enabler should be decided by the top managers in the initial stage. From ISM model, the present study suggested that "Government policies and supportive system" is found as a most essential enabler for the successful execution of sustainability concepts into supply chain management. Industries in India are to be aware of the sustainability requirement of product which means that the product should not only be cost efficient but also eco-friendly and effective for the society as well, so as to maintain the sustainability of a product over a long period. Ruling parties and government policies of India are the major reason for implementation of any social development programs. The findings of the study reveal that enablers having high driving power and low dependence are considered to align towards strategic planning of the sustainable practices. On the contrary, enablers having high dependence power and low driving power are aligned towards performance and result orientation. Consequently, for the better outcome independent enabler needs to give importance while implementing sustainable practices. The result obtained through present study and hierarchical model can be beneficial for companies to enhance the environmental, civilization and financial elements into supply chain management.

\section{Conclusions}

The ever increasing expectations of customers have put an intense force on market competition. In this scenario, the need for green environment and social welfare is very common. Public sectors as well as private sectors are facing problems in environmental related projects because of several natural degradations and improper utilization of available resources. It's a crucial requirement that every countryman should be conscious about the environment and social aspect. An organization must have to provide sustained development in its supply chain. For this, it is required to embrace the environment, social and economic aspects together. Many organizations are including sustainability as a part of their decision making strategies. Sustainable and trade-oriented supply chain management is expected to be obligatory to every firm to become the integral component. The selection of suitable strategy must set in the firms to create a difference between defining objective and becoming sustainable. This research has explored previous studies about sustainable practices and conducted expert discussion, with which 12 enablers were identified as key enablers. The ISM methodology and MICMAC analysis have been used find contextual relationships between these identified enablers and conceptulize the importance of each enabler. This study has explored that "Government policies and supportsystems" is examined as foremost enabler and occurred at lowest level in the ISM hierarchy, whereas "Economic advantages" and "Competitiveness of companies toward SSCM are occurring at the highest level of ISM hierarchy and keeps at least priority level. Although, the level of awareness has increased little bit, but it is not sufficient. Trade oriented sustainable must be put forward by scholars and practitioners with the considering triple bottom line aspect, rather than focusing on profitability. This study provides the significant results, which can be helpful in enhancing the performances of ecological, societal and financial.

\subsection{Future purview}

The proposed model is developed by using ISM technique, which has some limitations also. For example, the model is very much reliant on the judgments of the expert team. In the future, we plan to confirm this model using SEM analysis. Further, DEMATEL technique may be used for analysis of identifying enablers to deal with vagueness and biases associated with the present methodology. 


\section{References}

Ageron, B., Gunasekaran, A., \& Spalanzani, A. (2012). Sustainable supply management: An empirical study. International Journal of Production Economics, 140(1), 168-182.

Ahi, P., \& Searcy, C. (2013). A comparative literature analysis of definitions for green and sustainable supply chain management. Journal of Cleaner Production, 52, 329-341.

Amindoust, A., Ahmed, S., Saghafinia, A., \& Bahreininejad, A. (2012). Sustainable supplier selection: A ranking model based on fuzzy inference system. Applied Soft Computing, 12(6), 1668-1677.

Ansari, M. F., Kharb, R. K., Luthra, S., Shimmi, S. L., \& Chatterji, S. (2013). Analysis of barriers to implement solar power installations in India using interpretive structural modeling technique. Renewable and Sustainable Energy Reviews, 27, 163-174.

Balasubramanian, S. (2012). A hierarchical framework of barriers to green supply chain management in the construction sector. Journal of Sustainable Development, 5(10), 15-27.

Barari, S., Agarwal, G., Zhang, W. C., Mahanty, B., \& Tiwari, M. K. (2012). A decision framework for the analysis of green supply chain contracts: An evolutionary game approach. Expert Systems with Applications, 39(3), 2965-2976.

Hopkins, M. S., Townend, A., Khayat, Z., Balagopal, B., Reeves, M., \& Berns, M. (2009). The business of sustainability: what it means to managers now. MIT Sloan Management Review, 51(1), 20.

Beske, P., \& Seuring, S. (2014). Putting sustainability into supply chain management. Supply Chain Management: An International Journal, 19(3), 322-331.

Beske, P. (2012). Dynamic capabilities and sustainable supply chain management. International Journal of Physical Distribution \& Logistics Management, 42(4), 372-387.

Beske, P., Land, A., \& Seuring, S. (2014). Sustainable supply chain management practices and dynamic capabilities in the food industry: A critical analysis of the literature. International Journal of Production Economics, 152, 131-143.

Büyüközkan, G., \& Çifçi, G. (2012). A novel hybrid MCDM approach based on fuzzy DEMATEL, fuzzy ANP and fuzzy TOPSIS to evaluate green suppliers. Expert Systems with Applications, 39(3), 3000-3011.

Carter, C. R., \& Ellram, L. M. (1998). Reverse logistics: a review of the literature and framework for future investigation. Journal of Business Logistics, 19(1), 85.

Carter, C. R., \& Rogers, D. S. (2008). A framework of sustainable supply chain management: moving toward new theory. International journal of physical distribution \& logistics management, 38(5), 360-387.

Chen, C. C., Shih, H. S., Shyur, H. J., \& Wu, K. S. (2012). A business strategy selection of green supply chain management via an analytic network process. Computers \& Mathematics with Applications, 64(8), 2544-2557.

Chen, Y. S., Lai, S. B., \& Wen, C. T. (2006). The influence of green innovation performance on corporate advantage in Taiwan. Journal of Business Ethics, 67(4), 331-339.

Chien, M.K., \& Shih, L.H. (2007a). An empirical study of the implementation of green supply chain management practices in the electrical and electronics industries and their relation to organizational behavior. International Journal of Science and Technology, 4(3), 383-394.

Chien, M.K., \& Shih, L.H. (2007b). Relationship between management practice and organization performance under European Union directives such as ROHS, a case study on the electrical and electronics industry in Taiwan. African Journal of Environmental Science and Technology, 1(3), $37-48$.

Cognizant (2008). Creating a green supply chain information technology as an enabler for a green supply chain, cognizant working paper series.

De Brito, M. P., \& Van der Laan, E. A. (2010). Supply chain management and sustainability: procrastinating integration in mainstream research. Sustainability, 2(4), 859-870.

Dehghanian, F., \& Mansour, S. (2009). Designing sustainable recovery network of end-of-life products using genetic algorithm. Resources, Conservation and Recycling, 53(10), 559-570. 
Dewangan, D. K., Agrawal, R., \& Sharma, V. (2015). Enablers for competitiveness of Indian manufacturing sector: An ISM-fuzzy MICMAC analysis. Procedia-Social and Behavioral Sciences, 189, 416-432.

Diabat, A., \& Govindan, K. (2011). An analysis of the drivers affecting the implementation of green supply chain management. Resources, Conservation and Recycling, 55(6), 659-667.

Digalwar, A. K., \& Metri, B. A. (2004). Performance measurement framework for world class manufacturing. International Journal of Applied Management and Technology, 3(2), 83-101.

Dubey, R., Gunasekaran, A., Wamba, S.F., \& Bag, S. (2015). Building theory of green supply chain management using Total Interpretive Structural Modeling (TISM). IFAC-Papers On Line, 48(3), 1688-1694.

Easterby-Smith, M., Lyles, M. A., \& Peteraf, M. A. (2009). Dynamic capabilities: Current debates and future directions. British Journal of Management, 20(s1), S1-S8.

Fleischmann, M., Bloemhof-Ruwaard, J. M., Dekker, R., Van der Laan, E., Van Nunen, J. A., \& Van Wassenhove, L. N. (1997). Quantitative models for reverse logistics: A review. European journal of Operational Research, 103(1), 1-17.

Gold, S., Seuring, S., \& Beske, P. (2010). Sustainable supply chain management and interorganizational resources: a literature review. Corporate Social Responsibility and Environmental Management, 17(4), 230-245.

Gopalakrishnan, K., Yusuf, Y. Y., Musa, A., Abubakar, T., \& Ambursa, H. M. (2012). Sustainable supply chain management: A case study of British Aerospace (BAe) Systems. International Journal of Production Economics, 140(1), 193-203.

Greenberg, H. J. (1995). Mathematical programming models for environmental quality control. Operations Research, 43(4), 578-622.

Guide Jr, V. D. R., \& Van Wassenhove, L. N. (2009). OR FORUM-the evolution of closed-loop supply chain research. Operations Research, 57(1), 10-18.

Gungor, A., \& Gupta, S. M. (1999). Issues in environmentally conscious manufacturing and product recovery: a survey. Computers \& Industrial Engineering, 36(4), 811-853.

Hamel, G., \& Prahalad, C.K. (1989). Strategic intent. Harvard Business Review, 67(30), 63-76.

Jayant, A., \& Azhar, M. (2014). Analysis of the barriers for implementing green supply chain management (GSCM) practices: an interpretive structural modeling (ISM) Approach. Procedia Engineering, 97, 2157-2166.

Jayaratne, P., Styger, L., \& Perera, N. (2011). Sustainable supply chain management: using the Sri Lankan tea industry as a pilot study. 25th Annual Australia New Zealand Academy of Management Conference, 1, pp. 1-22, New Zealand: ANZAM.

Kannan, G., Pokharel, S., \& Kumar, P. S. (2009). A hybrid approach using ISM and fuzzy TOPSIS for the selection of reverse logistics provider. Resources, Conservation and Recycling, 54(1), 28-36.

Kaushik, A., Kumar, S., Luthra, S., \& Haleem, A. (2014). Technology transfer: enablers and barriersa review. International Journal of Technology, Policy and Management, 14(2), 133-159.

Kleindorfer, P. R., Singhal, K., \& Wassenhove, L. N. (2005). Sustainable operations management. Production and Operations Management, 14(4), 482-492.

Kumar, S., Luthra, S., \& Haleem, A. (2013). Customer involvement in greening the supply chain: an interpretive structural modeling methodology. Journal of Industrial Engineering International, 9(1), 1-13.

Kumar, S., Luthra, S., \& Haleem, A. (2014). Critical success factors of customer involvement in greening the supply chain: an empirical study. International Journal of Logistics Systems and Management, 19(3), 283-310.

Lamming, R., \& Hamapson, J. (1996). The environmental as a supply chain management issue. British Journal of Management, March Special Issue, 7(S1), 45-62.

Lee, S. Y. (2008). Drivers for the participation of small and medium-sized suppliers in green supply chain initiatives. Supply Chain Management: An International Journal, 13(3), 185-198.

Linton, J. D., Klassen, R., \& Jayaraman, V. (2007). Sustainable supply chains: An introduction. Journal of Operations Management, 25(6), 1075-1082. 
Luthra, S., \& Haleem, A. (2015). Hurdles in implementing sustainable supply chain management: An analysis of Indian automobile sector. Procedia-Social and Behavioral Sciences, 189, 175-183.

Luthra, S., Garg, D., \& Haleem, A. (2015). An analysis of interactions among critical success factors to implement green supply chain management towards sustainability: An Indian perspective. Resources Policy, 46, 37-50.

Luthra, S., Garg, D., \& Haleem, A. (2014). Green supply chain management: Implementation and performance-a literature review and some issues. Journal of Advances in Management Research, 11(1), 20-46.

Luthra, S., Garg, D., \& Haleem, A. (2014). Empirical analysis of green supply chain management practices in Indian automobile industry. Journal of The Institution of Engineers (India): Series C, 95(2), 119-126.

Luthra, S., Garg, D., Kumar, S., \& Haleem, A. (2012). Implementation of the green supply chain management in manufacturing industry in India using interpretive structural modeling technique. BPR Technologia: A Journal of Science, Technology \& Management, 1(1), 1-17.

Luthra, S., Kumar, V., Kumar, S., \& Haleem, A. (2011). Barriers to implement green supply chain management in automobile industry using interpretive structural modeling technique: An Indian perspective. Journal of Industrial Engineering and Management, 4(2), 231-257.

Maignan, I., \& Ralston, D. A. (2002). Corporate social responsibility in Europe and the US: Insights from businesses' self-presentations. Journal of International Business Studies, 33(3), 497-514.

Markley, M. J., \& Davis, L. (2007). Exploring future competitive advantage through sustainable supply chains. International Journal of Physical Distribution \& Logistics Management, 37(9), 763-774.

Min, H., \& Galle, W. P. (2001). Green purchasing practices of US firms. International Journal of Operations \& Production Management, 21(9), 1222-1238.

Mudgal, R. K., Shankar, R., Talib, P., \& Raj, T. (2010). Modelling the barriers of green supply chain practices: an Indian perspective. International Journal of Logistics Systems and Management, 7(1), 81-107.

Mudgal, R. K., Shankar, R., Talib, P., \& Raj, T. (2009). Greening the supply chain practices: an Indian perspective of enablers' relationships. International Journal of Advanced Operations Management, 1(2-3), 151-176.

Muduli, K., \& Barve, A. (2011). Role of green issues of mining supply chain on sustainable development. International Journal of Innovation, Management and Technology, 2(6), 484.

Muduli, K., \& Barve, A. (2013). Sustainable development practices in mining sector: a GSCM approach. International Journal of Environment and Sustainable Development, 12(3), 222-243.

Muduli, K., Govindan, K., Barve, A., Kannan, D., \& Geng, Y. (2013a). Barriers to green supply chain management in Indian mining industries: a graph theoretic approach. Journal of Cleaner Production, 47, 335-344.

Nielsen, S. N., \& Jørgensen, S. E. (2015). Sustainability analysis of a society based on energy studiesa case study of the island of Samsø (Denmark). Journal of Cleaner Production, 96, 12-29.

Nimawat, D., \& Namdev, V. (2012). An overview of green supply chain management in India. Research Journal of Recent Sciences, 1(6), 77-82.

Pagell, M., \& Shevchenko, A. (2014). Why research in sustainable supply chain management should have no future. Journal of Supply Chain Management, 50(1), 44-55.

Pagell, M., \& Wu, Z. (2009). Building a more complete theory of sustainable supply chain management using case studies of 10 exemplars. Journal of Supply Chain Management, 45(2), 37-56.

Porter, M.E., \& Kramer, M.R. (2006). Estrategia y sociedad. Harvard Business Review, 84(12), 42-56.

Rajaprasad, S. V. S., \& Chalapathi, P. V. (2015). Factors influencing implementation of OHSAS 18001 in Indian construction organizations: interpretive structural modeling approach. Safety and Health at Work, 6(3), 200-205.

Ravi, V., \& Shankar, R. (2005). Analysis of interactions among the barriers of reverse logistics. Technological Forecasting and Social Change, 72(8), 1011-1029.

Sarkis, J., \& Zhu, H. (2008). Information technology and systems in China's circular economy: Implications for sustainability. Journal of Systems and Information Technology, 10(3), 202-217. 
Sarkis, J. (1998). Evaluating environmentally conscious business practices. European journal of operational research, 107(1), 159-174.

Sarkis, J., Gonzalez-Torre, P., \& Adenso-Diaz, B. (2010). Stakeholder pressure and the adoption of environmental practices: The mediating effect of training. Journal of Operations Management, 28(2), 163-176.

Scupola, A. (2003). The adoption of Internet commerce by SMEs in the south of Italy: An environmental, technological and organizational perspective. Journal of Global Information Technology Management, 6(1), 52-71.

Seuring, S., \& Müller, M. (2008). From a literature review to a conceptual framework for sustainable supply chain management. Journal of Cleaner Production, 16(15), 1699-1710.

Seuring, S. (2011). Supply chain management for sustainable products-insights from research applying mixed methodologies. Business Strategy and the Environment, 20(7), 471-484.

Singh, M. D., Shankar, R., Narain, R., \& Agarwal, A. (2003). An interpretive structural modeling of knowledge management in engineering industries. Journal of Advances in Management Research, 1(1), 28-40.

Subramaniam, N., Wahyuni, D., Cooper, B. J., Leung, P., \& Wines, G. (2015). Integration of carbon risks and opportunities in enterprise risk management systems: evidence from Australian firms. Journal of Cleaner Production, 96, 407-417.

Toke, L. K., Gupta, R. C., \& Dandekar, M. (2012). An empirical study of green supply chain management in Indian perspective. International Journal of Applied Science and Engineering Research, 1(2), 372-383.

Tornatzky, L.G., Fleischer, M. and Chakrabarti, A.K., (1990). Processes of technological innovation.

Trowbridge, P. (2001). A case study of green supply-chain management at advanced micro devices. Greener Management International, 35, 121-135.

Walker, H., \& Jones, N. (2012). Sustainable supply chain management across the UK private sector. Supply Chain Management: An International Journal, 17(1), 15-28.

Walker, H., Di Sisto, L., \& McBain, D. (2008). Drivers and barriers to environmental supply chain management practices: Lessons from the public and private sectors. Journal of purchasing and supply management, 14(1), 69-85.

Wang, Z., \& Sarkis, J. (2013). Investigating the relationship of sustainable supply chain management with corporate financial performance. International Journal of Productivity and Performance Management, 62(8), 871-888.

Winkler, H. (2010). Sustainability through the implementation of sustainable supply chain networks. International Journal of Sustainable Economy, 2(3), 293-309.

Lin, C. Y., \& Ho, Y. H. (2008). An empirical study on logistics service providers' intention to adopt green innovations. Journal of Technology Management \& Innovation, 3(1), 17-26.

Zhou, Z., Cheng, S., \& Hua, B. (2000). Supply chain optimization of continuous process industries with sustainability considerations. Computers \& Chemical Engineering, 24(2), 1151-1158.

Zhu, Q., Sarkis, J., \& Lai, K. H. (2007a). Initiatives and outcomes of green supply chain management implementation by Chinese manufacturers. Journal of Environmental Management, 85(1), 179-189.

Zhu, Q., Sarkis, J., \& Lai, K. H. (2007b). Green supply chain management: pressures, practices and performance within the Chinese automobile industry. Journal of Cleaner Production, 15(11), 1041-1052.

Zhu, Q., Sarkis, J., \& Lai, K. H. (2008). Green supply chain management implications for "closing the loop". Transportation Research Part E: Logistics and Transportation Review, 44(1), 1-18.

Zhu, Q., Sarkis, J., \& Lai, K. H. (2008). Confirmation of a measurement model for green supply chain management practices implementation. International Journal of Production Economics, 111(2), 261-273.

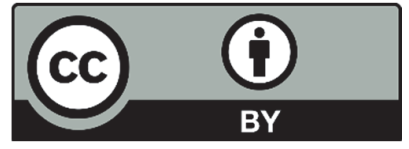

(C) 2016 by the authors; licensee Growing Science, Canada. This is an open access article distributed under the terms and conditions of the Creative Commons Attribution (CC-BY) license (http://creativecommons.org/licenses/by/4.0/). 